\title{
Induced response against herbivory by chemical information transfer between plants
}

\author{
Wellington G. Campos ${ }^{1 *}$, Ana P. Faria ${ }^{2}$, Maria Goreti A. Oliveira ${ }^{3}$ and Hérica L. Santos ${ }^{4}$ \\ ${ }^{1}$ Departamento de Engenharia de Biossistemas, Universidade Federal de São João del Rei, 36301-160 \\ São João del Rei, MG, Brasil \\ 2 Programa de Pós-Graduação em Biologia Vegetal, Universidade Federal de Minas Gerais, 31270-901 Belo \\ Horizonte, MG, Brasil. \\ ${ }^{3}$ Departamento de Bioquímica e Biologia Molecular, Universidade Federal de Viçosa, 36700-000, Viçosa, MG, Brasil. \\ ${ }^{4}$ Campus Centro-Oeste Dona Lindu, Universidade Federal de São João del Rei, 35501-296 Divinópolis, MG, Brasil \\ *Corresponding author: wgcampos@ufsj.edu.br \\ Received: 15 May 2008; Returned for revision: 09 July 2008; Accepted: 09 October 2008
}

INDUCED RESPONSE AGAINST HERBIVORY IN PLANTS: Plants respond to herbivores and pathogens attack with increased emission of volatile organic compounds. These molecules act as indirect defences when attracting natural enemies of herbivores and thus benefit the plant. It remains controversial whether undamaged plants identify chemicals released by closely located, damaged plants and respond to them by increasing their defensive barriers against an imminent attack. Although the Talking Trees Hypothesis was published 25 years ago, only recently the most sceptical scientists have been convinced. The induced response to herbivory by interplant information transfer has been found in two plant-herbivore systems. However, the universality of the phenomenon and its ecological and evolutionary relevance remain unclear. The integration of Molecular Biology, Biochemistry, Physiology, and Ecology begin to shed light on the mechanisms of the signal transfer. This integrative approach has developed new and more sensitive tools for identification of complex volatile mixtures and for understanding the process of biosynthesis, emission, transportation and reception of signals.

Key Words: induced resistance, induced defense, insect-plant interaction, interplant air signalling, interplant communication, talking trees.

Respostas contra herbivoria induzidas pela transferência de informação entre plantas: Plantas respondem ao ataque de herbívoros e patógenos com liberação de compostos orgânicos voláteis. Essas moléculas funcionam como defesas indiretas quando atraem inimigos naturais dos herbívoros e assim beneficiam a planta emissora. Uma questão controversa é se plantas vizinhas não-atacadas captam esses voláteis e respondem aumentando suas barreiras defensivas contra um ataque iminente. Apesar do seu forte apelo popular e da Talking Trees Hypothesis estar completando 25 anos, só recentemente os mais céticos estão sendo convencidos. Temse aceitado que respostas induzidas pela transferência de informação entre plantas ocorrem em pelo menos dois sistemas plantaherbívoro. No entanto, o grau de generalização do fenômeno e a dimensão da sua importância ecológica e evolutiva permanecem desconhecidos. Uma recente abordagem multidisciplinar, integrando Biologia Molecular, Bioquímica e Fisiologia à Ecologia, acena com novas e mais poderosas ferramentas metodológicas para esclarecer os processos de biossíntese, emissão, transporte e recepção dos sinais pelas plantas. Essa abordagem tem fornecido o suporte mecanicista adicional às evidências ecológicas da defesa induzida da planta, manifestada e mensurada mediante respostas ecofisiológicas e comportamentais dos insetos herbívoros.

Palavras-chave: compostos orgânicos voláteis, comunicação entre plantas, defesa induzida, interação inseto-planta, resistência induzida, percepção oportunista de sinais 


\section{INTRODUCTION}

All organisms are under selective pressure to maximize reproductive success. To gain information about environmental conditions, organisms must take advantage of information provided by their neighbours, particularly chemical signals. Animals adjust behavioural decisions and increase their Darwinian fitness by exploring different sources of information on resources, competitors, or natural enemies (Krebs and Davis, 1997). Protists, unicellular organisms without nervous system, have high sensibility to external stimuli and respond to them in relatively complex ways (Brusca and Brusca, 2007). Analogous to the reasoning for animals and protists, one can expect that plants are capable to get information about specific environmental changes and respond to any changes by adjusting their phenotypes. A strong and positive selective pressure favouring information perception by plants must be expected. In fact, plant behaviours have been recently acknowledged as widespread, diverse, and sophisticated (Karban, 2008).

Transfer of chemicals between plants has been commonly studied in the context of plant nutrition (mutualism) and competition (allelopathy) (Bruin et al., 1995; Mallik et al., 2000). However, the challenge is to know whether organic compounds released by plants can be used by their neighbours as indicators of environmental changes, a subject still treated with scepticism. The debate on interplant chemical communication has been historically placed in the context of herbivory. Rhoades (1983) first proposed the Talking Trees Hypothesis whereby damaged trees might warn their neighbours from an imminent herbivore attack, resulting in increased resistance. The Talking Trees Hypothesis and related were strongly criticized for their methodological approach and several ecologists rejected the hypothesis. Carefully controlled experiments over the last decade however, have shown that interplant communication is possible, even though the phenomenon is apparently not widely distributed over the plant kingdom. This review is not meant to exhaust the discussion on the role of interplant communication in preventing herbivore and pathogen attacks. It is a short synthesis of the recent empirical findings supporting the phenomenon and its biochemical, physiological, ecological and adaptive mechanisms.

\section{INDUCED DEFENCE BY INTERPLANT COMMUNICATION}

Induced responses are defined as plant changes resulting from damage or stress. These traits may or may not affect herbivores, and they may or may not benefit the plant when herbivores are present. Induced resistance is an induced response capable of reducing herbivore survival, reproductive output, or preference for the plant. Induced resistance is viewed from the herbivore's point of view. It does not necessarily benefit the plant, and the definition makes no assumptions about the factors that led to the evolutionary origin or maintenance of the trait. Induced defence is an induced response that improves the plants Darwinian fitness. Induced defence is viewed from the plant's point of view, the plant benefits from the response even though herbivores may be unaffected. This definition includes mechanisms that reduce damage to plants as well as those that increase tolerance to a given level of damage (Karban and Baldwin, 1997). Induced responses are currently know for several plants and may be present throughout the whole plant kingdom (Karban and Baldwin, 1997; Agrawal et al., 1999; Tuzun and Bent, 2005).

In general, attacks of herbivores or pathogens induce rearrangements in nutrient allocation among plant parts, promote the development of physical barriers, and stimulate production of protease inhibitors, oxidative enzymes, and a wide variety of secondary metabolites (Bennett and Wallsgrove, 1994; Karban and Baldwin, 1997). Several of these responses have been accepted as directly induced defences (Roda and Baldwin, 2003). However, herbivore-damaged plants also release mixtures of volatile organic compounds (VOCs) (Sabelis et al., 1999; Pichersky and Gershenzon, 2002; Arab and Bento, 2006; Baldwin et al., 2006). These VOCs are hardly released by undamaged plants and by those mechanically or artificially damaged in the absence of herbivores. In other cases, only small qualitative differences are found between VOCs released by mechanically and naturally damaged plants (Dicke, 1999b). Mixture composition is usually speciesspecific, and can also be specific for the herbivore species causing damage (Dicke, 1999a). Plant response can be triggered by specific substances in herbivore saliva (Turlings and Tumlinson, 1992, Alborn et al. 2003). The main question is why are these VOCs released by the attacked plant? If volatilization is not an occasional chemical phenomenon, then what are the adaptive advantages for the plant? 
There are several reports, that VOCs, which attract natural enemies of herbivores, are released by damaged plants (Sabelis et al., 1999; Kessler and Baldwin, 2001; Arab and Bento, 2006). These VOCs act as indirect induced defences, considering that their release increases Darwinian fitness of the plant by increasing seed production (van Loon et al., 2000). VOCs released by attacked plants also seem to indirectly induce closely located, undamaged plants to produce defences, the subject on which our review is focused.

\section{ECOLOGICAL STUDIES OF INTERPLANT COMMUNICATION}

Rhoades (1983) was the first to find lower performance of herbivore insects on trees exposed to volatile compounds from conspecific infested trees. He proposed that plants are capable to capture warning signals from damaged neighbours and thus produce defensive metabolites against herbivores. At the same time, Baldwin and Schultz (1983) found elevated levels of phenolic compounds in plants exposed to VOCs from damaged conspecific individuals, but did not go on to show that the induction of phenolic compounds resulted in increased plant resistance.

Fowler and Lawton (1985) criticized those early reports. According to their interpretation, the experiments had no true replication, some of the results could be explained by alternative hypotheses that had not been tested. Moreover Fowler and Lawton stated that there was overestimation of small effects obtained in the laboratory for field conditions. The authors performed a field experiment. Four weeks after manual defoliation, they found no difference in insect attack between individuals located near damaged plants and those near the undamaged control-plants. Their experimental design, however, was also criticized, because any short-term effects may have been not recognized in the course of the month following the treatment (Bruin et al., 1995).

Hawkioja et al. (1985) found positive correlation between distance to the closest defoliated tree and herbivore performance (growth, survival and fecundity). These researchers controlled the time of response, worked in field conditions, included and rejected alternative hypotheses, and carefully avoided pseudoreplication. Hence, their results could be explained by airborne information transfer between damaged and undamaged plants. Other experiments with different plant-herbivore systems have been carried out later. Some failed to find evidence (e.g. Lin et al., 1990; Preston et al., 1999; Sotka et al., 2002), but several have contributed to the acceptance of information transfer between plants (Bruin et al., 1995; Shonle and Bergelson, 1995; Karban and Baldwin, 1997; Dicke and Bruin, 2001; Baldwin et al., 2002; Baldwin et al., 2006, Heil and Silva Bueno, 2007).

Two plant-herbivore systems tested in the last 10 years have provided the most convincing results. One is the model for Artemisia tridentata, Nicotiana attenuata, six species of grasshoppers and other generalist insects (Karban et al., 2000; Karban, 2001; Karban et al., 2003). The sagebrush ( $A$. tridentata) constitutively releases a complex mixture of volatile compounds, with a large number of constituents. They exhibit a quantitative change after damage and hence are candidates for potential signals (Preston et al., 2001). The wild tobacco (N. attenuata) was transplanted near undamaged sagebrushes (control) and closely located plants whose leaves were later artificially damaged or defoliated by herbivores. Field and supplementary laboratory tests were carried out. Wild tobacco near damaged sagebrushes significantly increased the production of defensive metabolites. Tobacco response was similar for natural herbivore damage and artificial damage on sagebrush. Herbivore performance was also lower in tobacco near damaged sagebrushes. The authors concluded that tobacco increased its resistance due to the damages to the neighbouring sagebrushes. Resistance decreased with increases in distance from the damaged neighbour; i.e., the closer to the emitting plant, the greater the receptor resistance. In this system, damaged tobacco does not induce defensive responses in undamaged conspecific neighbours (Karban et al., 2000; Karban, 2001; Karban et al., 2003). Although wild tobacco near damaged sagebrush produced more flowers and seeds, the adaptive benefits remain unclear (Karban and Maron, 2002).

One recurring point of the controversy on the role of VOCs signaling between plants has been the distance over which the herbivore-induced volatiles can be received (Baldwin et al., 2002; Kaban et al., 2003; Kessler et al., 2006). Therefore, the fact that $N$. attenuata grows very close to $A$. tridentata in nature may be crucial for the observed effects in that system. Significant effect was only detected, when the wild tobacco was growing within $15 \mathrm{~cm}$ of the damaged sagebrush 
(Karban and Maron, 2002; Karban et al., 2003). Withinplant signaling via herbivore-induced plant volatiles (HIPV) is consistent with short transmission distances (Gershenzon, 2007; Heil and Silva Bueno, 2007), but also provides tangible benefit to the emitting plant. Thus, although between-plant signaling may remain controversial, the potential role of VOCs in signaling within-plants is recently gaining new interest in the mechanisms by which plants respond to HIPVs (Frost et al., 2008).

The second model is about the conspecific herbaceous plants Alnus glutinosa and their main natural enemy, the alder leafcutter beetle Agelastica alni (Dolch and Tscharntke, 2000; Tscharntke et al., 2001). The plant is usually defoliated by the alder beetle, and it is under strong and periodical selective pressure to produce defensive responses. The alder beetles trigger both rapid and delayed induced resistance. Resistance among conspecific undamaged neighbouring plants was assessed by field tests with 10-plant blocks; one of them was randomly selected to be manually defoliated. Laboratory tests were done to corroborate and quantify field results. Natural damage by alder beetles increased with distance from the artificially defoliated conspecific plants. The results indicate induced resistance not only in the damaged plant but also in neighbours. Beetles avoided plants nearer the damaged plant for feeding or oviposition in the field and in laboratory (Dolche and Tscharntke, 2000; Tscharntke et al., 2001).

These recent studies encourage the investigation of new plant-herbivore systems to establish the degree of generalization of the phenomenon (e.g. Karban et al, 2004), although arguments against its universality have been pointed out (Farmer, 2001). It may also be very fruitful to obtain direct evidences of physiological and biochemical mechanisms for plant-to-plant signal transmission. This mechanistic approach could offer valuable support to evidence based on herbivore performance and behaviour.

\section{THE MEDIUM OF INTERPLANT SIGNAL TRANSFER}

Conspecific plants and plants of different species interconnect in several ways, the most obvious being by direct contact between roots or haustorias. Connection also occurs through microorganisms such as mycorrhizal fungi. In all these cases, substances such as minerals and carbohydrates are transferred between plants. Interplant contact is not only physical; water and air also transfer chemicals through root exudates or through volatile substances (Bruin et al., 1995). Therefore, a key point in understanding chemical communication between damaged and undamaged plants is to identify the medium where signal transfer occurs.

At least one study has been reported on subterranean information transfer between plants (Hawkioja et al., 1985), but most studies on interplant communication reports on volatile compounds (Bruin et al., 1995; Bruin and Dicke, 2001; Dicke and Bruin, 2001; Farmer, 2001; Karban, 2001; Preston et al., 2001; Tscharntke et al., 2001; Baldwin et al., 2002; 2006; Karban et al., 2006; Kost and Heil, 2006). Some studies were intentionally designed to exclude subterranean information transfer (Farmer and Ryan, 1990; Karban et al., 2000). Nonetheless, although most studies are on aerial communication, the strong possibility of communication via soil should not be abandoned (Chamberlain et al., 2001; Dicke and Dijkman, 2001). In methodological terms, it is not easier to study the transfer of aerial signals in field conditions than to study subterranean signals, because plants can receive other airborne signals and also be affected by wind, temperature and abiotic stress. Small artificial changes in air flow among neighbours were enough to decrease resistance of signalreceiving plants (Karban et al., 2006)

There are three other steps of volatile transfer from plant to plant besides transportation itself are the release by the emitter plant, absorption, and perception by the receiver plant. Due to the chemical and environmental complexity in all four steps, the challenge is not only to determine the active component of the signal but also to understand the mechanisms of enzyme control and specific metabolic pathways in signal-emitting and signal-receiving plants.

\section{CHEMICAL MEDIATION IN INTERPLANT COMMUNICATION}

Evidence of physiological and biochemical responses by undamaged plants to VOCs emitted by damaged plants has been reported. Purified plant compound volatiles applied on cotton leaves increased production of antifungal phytoalexins (Zeringue, 1992). Fecundity of the aphid Myzus nicotianae 
decreased in tobacco leaves ( $N$. tabacum) receiving volatile compounds emitted by crushed tomato leaves (Hildebrand et al., 1993). Zeringue (1987) found that terpenoids production in undamaged cotton (Gossypium hirsutum) leaves increased when exposed to a natural mixture of volatile compounds emitted by leaves infected with Aspergillus flavus. However, healthy leaves exposed to volatile mixtures of artificiallydamaged cotton leaves responded differently. Therefore, composition of the volatile mixture can be intimately related to infection or herbivory.

Kost and Heil (2006) tested the efficiency of applying natural or synthetic VOCs to induce indirect defence against herbivore in undamaged Phaseolus lunatus. They found an increase in extrafloral nectar secretion, as well as greater attraction of parasitoids and predators, reduction of damage caused by herbivores, and higher flower and leaf production. Synthetic mixtures can therefore produce the same effects on the receiver as VOCs naturally released by damaged plants.

For a volatile compound to be as a plant-plant airborne signal in a natural setting, certain criteria have to be met. If the signal is constitutively released, independent of damage, then the signal from damaged plants must be released in significantly greater quantities for the receiver plant to distinguish it. Alternatively, qualitative, rather than quantitative, changes in the signal could provide the information. The signal must be received, and not only emitted, at physiologically active levels. The dilution that occurs as a signal, which is released into the environment, represents the most onerous challenge for a potential plant-plant signal (Firn and Jones, 1995).

Once released into the headspace of the emitter, the potential signal has to be absorbed and perceived by the receiver plant in active physiological concentration. Direction and dynamics of the transport are dictated by temperature, convective transport, and wind for above-ground signalling or water for below-ground signalling. Small highly volatile compounds such as ethylene, methanol, isoprene, acrolein, methacrolein and some monoterpenes diffuse rapidly into the headspace and are diluted in the atmosphere. For such compounds, signalling function is likely limited to the foliage of the emitter (as a systemic within-plant signal) and of neighbours with intertwined canopies. On the other hand, compounds with less volatility such as terpene alcohols, methyl jasmonate, and methyl salicylate are more likely to work as long-distance signals. Because of the slower dispersal and development of plumes of higher concentration, such signals would be carried farther in functional levels by turbulent atmospheric flows (Baldwin et al., 2006). However, the greater the distance over which a signal is to function, the greater the released amounts must be (Firn and Jones, 1995). Once these criteria are met, a compound may be considered as a potential airborne signal.

There are some potential signals that mightactas mediators of plant communication, but conclusive findings that any of the compounds are emitted, transported, absorbed, and perceived by plants are still unknown. Included among the compounds that are thought to be involved in interplant communication are two jasmonates [cis-jasmone and methyl jasmonate (MeJA)], the methyl ester of a phenolic compound often linked to pathogen attack [methyl salicylate (MeSA)], terpenes [ $\beta$-ocimene, (E)-4,8-dimethyl-1,3,7-nonatriene (DMNT) and (E,E)-4,8,12trimethyl-1,3,7,11-tridecatetraene (TMTT)], and some C6-C10 alkenals and alkanals (Preston et al., 2001). Since the pioneer of Farmer and Ryan (1990), jasmonates have been the most studied compounds as well as the stronger candidates for aerial signals in interplant communication (Shonle and Bergelson, 1995; Farmer, 2001; Preston et al., 2001; 2004). Besides of their potential role as mediators of interplant communication, jasmonates play a key function in genetic and metabolic regulation, in defence, in response to wounding, in plant reproduction (Liechti and Farmer, 2002), and inhibition of seed germination of competitors (Karban 2007).

Numerous physiological responses in plants are elicited by MeJA. Carefully controlled laboratory experiments revealed that resistance genes can be activated in undamaged young tomato (Solanum lycopersicom), alfalfa (Medicago sativa), and tobacco ( $N$. tabacum) plants, after exposure to the vapour of MeJA. In all three species, MeJA, originating either from a synthetic solution or from sagebrush (A. tridentata) twigs with undamaged leaves, was shown to induce the biosynthesis of proteinase inhibitors (PIs), the production of which is also enhanced by herbivore or pathogen attack (Bruin et al., 1995). Volatile synthetic MeJA can also induce insect resistance in cabbage and tobacco, production of alkaloids in Catharanthus and Cinchona seedlings, polyphenol oxidase activity (PPO) in tomato, indolyl glucosinolates in Brassica napus, and furanocumarins in Apium graveolens (Preston et al., 2001, and references therein). Induced responses by MeJA in $N$. 
attenuata include changes in levels of nicotine, phenolics, flavonoids, Pls and PPOs, as well as volatilization of terpenes, alcohols and aldehydes (Preston et al., 2001, and references therein).

\section{PLANT RECEPTION AND RESPONSE TO VOLATILE SIGNALS}

Are all plants equally capable of receiving and responding to signals released by damaged neighbours? Are there categorical generalizations for plants that transfer more or less signals? Once we accept interplant signalling, a wide range of new hypotheses emerges. The optimal defense theory (ODT) predicts that defense has a cost, and constitutive defenses should be preferentially employed when plants or plant tissues will have higher probabilities of being attacked. On the other hand, inducible defenses may be usually employed by plants with lower probabilities of attack (Rhoades and Cates, 1976; Zangel and Bazzaz, 1999). Perennial plants may be exposed much more frequently to herbivores than annuals, and annuals are thought to be under strong selection to grow quickly at the expense of investing in defence (Herms and Mattson, 1992). Therefore, herbaceous species should more often undertake induced rather than constitutive defence, also through the reception of signals from damaged neighbouring plants (Dicke and Bruin, 2001). It is also expected that the ability to respond to such signals is not constant for all individuals of the species nor for the same individual in time. For example, the level of nutritional and water stress (Mattson, 1980; Mattson and Haack, 1987), previous experiences with herbivore attacks (Agrawal, 1998; Karban et al., 1999), and the phenological age of the plant (Boege and Marquis, 2005) are some of the potential sources of interference on individual phenotypical responses.

The information-receiving plants may also show a 'silent' preparatory response besides the ultimate external evidence. In response to damage-related volatile compounds, undamaged plants could somehow become alerted. The exposure to the volatiles informs them of potential danger nearby. Since there is always the possibility that the plant will not actually become attacked, it could pay to postpone expensive defensive measures until they are actually needed (Bruin and Dicke, 2001). The physiological warning stimulated by damaged neighbours would lead to faster defensive responses as soon as herbivore attack starts.

Although induced defenses allow plants to avoid the costs of implementing defenses in the absence of enemies, plants may suffer considerable damage during the time required to mount defenses once attack occurs. To compensate for this vulnerability, some plants appear to prime specific defenses in response to environmental cues that reliably indicate an increased probability of attack before they actually experience an herbivore or pathogen. In a recent review, Forst et al. (2008) focused on priming responses of plants to herbivores. In plant defense, priming is a physiological process by which a plant prepares to more quickly or aggressively respond to future biotic or abiotic stress, and the condition of readiness achieved by priming has been termed the "primed state". Because priming initiates a state of readiness that does not confer resistance per se but rather allows for accelerated induced resistance once an attack occurs, one presumed benefit of priming is that it does not impose the costs associated with full implementation of an induced defense response. This state of alertness, or 'silent' response involving preparations for the attack, could also be less costly than induction of direct or indirect defences.

Hidden or silent responses by exposed plants may easily remain not recognized when only the outside of the plant is assayed, and the finding of no effect in a bioassay may not be very informative. A combination of more specific chemical and biomolecular assays may be necessary (Bruin and Dicke, 2001). Ecological assays provide ultimate information on effects of receiving plants on performance and behaviour of their antagonistic (herbivores and pathogens) or protagonists (natural enemies of herbivores). On the other hand, biochemical and physiological tests directly measure the internal response of the plant and its intensity (Dolch and Tscharntke, 2000; Karban et al., 2000; 2003; Karban, 2001; Preston et al., 2001; Tscharntke et al., 2001; Preston et al., 2004).

New perspectives for the functional analysis of induced defence, plant volatile compounds, and VOC-induced priming have been brought by biochemistry and molecular biology (Roda and Baldwin, 2003; Dudareva et al., 2004; Baldwin et al., 2006, Kessler et al., 2006; Ton et al., 2006; Engelberth et al., 2007; Zheng and Dicke, 2008). The approach offers more sensitive tests, although they can point to responses whose importance will have to be assured by ecological tests (Bruin 
and Dicke, 2001). One solution to the problems of ecological realism in between-plant signalling studies is to use mutant or transgenic plants. Individuals that cannot release (mute plants) or perceive (deaf plants) particular components of the volatile blends have been used to accommodate the low ecological realism of laboratory studies on interplant signalling. Mute and deaf plants in combination with wild-type plants have been seen as a tool for dissection of complex volatile mixtures and understanding of signal emission, transportation, and reception processes (Baldwin et al., 2006; Paschold et al, 2006).

\section{WHY SHOULD PLANTS COMMUNICATE?}

If damaged plants transfer volatile compounds to undamaged plants, then the follow-up intriguing questions are on the evolutionary mechanisms of plant signalling. The notion that plants respond to cues that have been released by damaged neighbours is consistent with natural selection acting at the individual level (Karban and Maron, 2002). On the other hand, why should damaged plants dispense information that other, unrelated, individuals can use? Are there adaptive benefits also for the emitting plant or is the perception of volatile compounds an exclusively opportunistic reaction of some plants?

Between-plant signaling via HIPVs should fit, alongside induced defense responses, within the larger theoretical framework of the ODT (Zangerl and Bazzaz, 1992; Stamp, 2003). The ODT is predicated on the fundamental premise that plants evolve and allocate defenses in a way that maximizes individual inclusive Darwinian fitness. One prediction of ODT is that production and allocation costs associated with induced defenses should exert a strong selective pressure for induced defenses to be low or absent when herbivores are absent but increased when herbivores are present (Frost et al., 2008). Conceptually, between-plant signaling via HIPVs should be subject to the same predictions as other induced responses associated with plant defense. Thus, induced responses by interplant transfer of signals presumably have lower costs that make constitutive expression disadvantageous. Plants have developed effective structures and metabolites against herbivores and pathogens, however, most of these defences have high maintenance costs and they are produced only during the attack. In these cases, there is an induced production of defence metabolites that do not have to be permanently stored in plant tissues (Karban and Baldwin, 1997). There are several adaptive situations where plants should employ inducible defences rather than constitutive defences (Agrawal and Karban, 1999). When damaged plants produce metabolites against herbivores and also spread volatile compounds in the area, undamaged neighbours that are sensitive to these signals get benefits by producing defences before the imminent attack. Since inducible defences take some time to become effective (Karban and Baldwin, 1997), the ability to predict an imminent attack solves this delay (to become effective too late) and awards adaptive superiority to the sensitive individuals. However, the fitness consequences of resistance induced by volatile compounds released by damaged neighbours remain empirically unclear (Karban and Maron, 2002).

A critical evolutionary issue of interplant communication is how the damaged plant can exploit the emitted information for its own benefit. The transfer of information between plants could provide an immediate reciprocal advantage when their relation is sufficiently close of kin. Informing a neighbour may benefit the sender to the extent that this would benefit the gene pool of the whole group. When the receiving plant defends itself, the sender could experience a benefit by being part of a group of plants with an alarm defence system that makes it less profitable for herbivores. In that case, herbivores will profit from foraging a distance away (Bruin et al., 1995; Bruin and Dicke, 2001; Dicke and Bruin, 2001). Besides, variations in wind direction change the path of alarm signals and help the receiving plant to send the signal back to the emitting plant (Bruin et al., 1995). Nevertheless, relatedness between sender and receiver plants is not a requirement for mutual advantage. If combined efforts of all plants would result in a higher number of natural enemies locally and, consequently, in less herbivore damage, natural selection is expected to favour such a warning system. In this case, benefits to the senders are dependent on the receiver ability to respond (Bruin and Dicke, 2001).

Adaptive benefits for the emitting plant are still limited to hypotheses and no empirical evidence can so far support them. Natural selection most likely favours the development of opportunistic perception (eavesdropping) of cues released (voluntarily or involuntarily) by damaged plants, and respond by tailoring their phenotypes to enhance their own fitness. In fact, appealing terms such as "interplant communication" 
and "talking trees" have been treated with distrust, because they do not reflect the real evolutionary dimension of the phenomenon. The term "eavesdropping" between plants has been recommended (Karban and Maron, 2002).

\section{CONCLUDING REMARKS}

Differently from animal communication, which can be readily observed through conspicuous behavioural responses, research on interplant communication is rendered difficult due to the lack of appropriate assays to detect trustful and ecologically relevant responses. Nevertheless, recent studies with two plant-herbivore systems have provided evidence consistent with airborne plant-plant signalling in nature. The degree of generalization or universality of the phenomenon must therefore be established because its ecological and evolutionary importance will only be defined after new systems are known.

Most studies on interplant communication report on volatile aerial signals, which seem to be efficient in reducing herbivore attack on receiving plants. However, the possibility of soilborne transfer of chemicals through the plant root system has still not been abandoned. Included among the organic compounds that are thought to be involved in interplant communication, methyl jasmonate has been the stronger candidate for an aerial signal. However, the challenge is not only to determine the active component of the signal but mainly understand the mechanisms of enzyme control and specific metabolic pathways in signal-emitting and signalreceiving plants. Much has been expected from the integration of molecular biology, biochemistry, physiology, and ecology approaches. This integration will provide answers, based on more sensitive assays, to questions of ecologists. A major challenge for currentbiology is to integrate research approaches that address different levels of biological organization, from molecular to ecological systems (Zheng and Dicke, 2008). Interplant communication is a research topic that properly suits the practice of interdisciplinary cooperation.

Many questions can still be raised and interplant communication is a fertile field for new hypotheses. Is the damage extent important? How long is the signal emitted? How long does the induced resistance last? Which environmental conditions affect plant communication and how? Does the induced indirect defence affect herbivore populations? Does interplant communication provide real benefits for receiving and emitting plants? Can communication affect plant abundance and distribution? There are still more questions than answers, but the future scope of interplant communication will open new perspectives applied to pest and disease control in plants. Volatile mixtures directly sprayed on plants against herbivores and pathogens, and the development of plants that are more sensitive to defence inducers are some of the possibilities. However, the path to be followed is long and very few scientists have currently worked to solve the instigating and challenging subject of interplant communication.

\section{REFERENCES}

Agrawal AA (1998) Leaf damage and associated cues induce aggressive ant recruitment in a neotropical ant-plant. Ecology. 79:2100-2112.

Agrawal AA, Karban R (1999) Why induced defenses may be favored over constitutive strategies in plants. In: Tollrian R, Harvell CD (eds), The Ecology and Evolution of Inducible Defenses, pp.45-61. Princeton University Press, Princeton.

Agrawal AA, Tuzun S, Bent E (eds) (1999) Induced Plant Defenses Against Pathogens and Herbivores: Biochemistry, Ecology, and Agriculture. American Phytopathological Society Press, Saint Paul, Minnesota.

Alborn HT, Brennan MM, Tumlinson JH (2003) Differential activity and degradation of plant volatile elicitors in regurgitant of tobacco hornworm. (Manduca sexta) larvae. J. Chem. Ecol. 29:1357-1372.

Arab A, Bento JMS (2006) Plant volatiles: new perspectives for research in Brazil. Neotrop. Entomol. 35:151-158.

Baldwin IT, Halitschke R, Paschold A, von Dahl CC, Preston CA (2006) Volatile signaling in plant-plant interactions: "Talking Trees" in the genomics era. Science. 311:812-815.

Baldwin IT, Kessler A, Halitschke R (2002) Volatile signaling in plant-plant herbivore interactions: what is real? Curr. Opin. Plant Biol. 5:1-4.

Baldwin IT, Schmelz EA (1996) Immunological "memory" in the induced accumulation of nicotine in wild tobacco. Ecology. 77:236-246.

Baldwin IT, Schultz J (1983) Rapid changes in tree leaf chemistry induced by damage: evidence for communication between plants. Science. 221:277-279.

Bennett RN, Wallsgrove RM (1994) Secondary metabolites in plant defense mechanisms. New Phytol. 127:617-633.

Boege K, Marquis RJ (2005) Facing herbivory as you grow up: the ontogeny of resistance in plants. Trends Ecol. Evol. 20:441-448.

Bruin J, Dicke M (2001) Chemical information transfer between wounded and unwounded plants: backing up the future. Biochem. Syst. Ecol. 29:11031113.

Bruin J, Sabelis MW, Dicke M (1995) Do plants tap SOS signals from their infested neighbours? Trends. Ecol. Evol. 10:167-170.

Brusca RC, Brusca GJ (2007) Invertebrados. $2^{\text {th }}$. ed. Guanabara, Rio de Janeiro.

Chamberlain K, Guerrieri E, Pennacchio F, Pettersson J, Pickett JA, Poppy GM, Powell W, Wadhams LJ, Woodcock CM (2001) Can aphid-induced plant signals be transmitted aerially and through the rhizosphere? Biochem. Syst. Ecol. 29:1063-1074.

Dicke M (1999a) Are herbivore-induced plant volatiles reliable indicators of herbivore identity to foraging carnivorous arthropods? Entomol. Exp. Appl. 92:131-142. 
Dicke M (1999b) Evolution of induced indirect defense of plants. In: Tollrian R, Harvell CD (eds), The Ecology and Evolution of inducible Defenses, pp.62-88. Princeton University Press, Princeton.

Dicke M, Bruin J (2001) Chemical information transfer between plants: back to the future. Biochem. Syst. Ecol. 29:981-994.

Dicke M, Dijkman H (2001) Within-plant circulation of systemic elicitor of induced defence and release from roots of elicitor that affects neighbouring plants. Biochem. Syst. Ecol. 29:1075-1087.

Dolch R, Tscharntke T (2000) Defoliation of alders (Alnus glutinosa) affects herbivory by leaf beatles on undamage neighbours. Oecologia. 125:504-511.

Dudareva N, Pichersky E, Gershenzon J (2004) Biochemistry of plant volatiles. Plant Physiol. 135:1893-1902.

Engelberth J, Seidl-Adams I, Schultz JC, Tumlinson JH (2007) Insect elicitors and exposure to green leafy volatiles differentially upregulate major octadecanoids and transcripts of 12-oxo phytodienoic acid reductases in Zea mays. Mol. Plant Microbe Interact. 20:707-716.

Farmer EE (2001) Surface-to-air signals. Nature. 411:854-856.

Farmer EE, Ryan CA (1990) Interplant communication: airborne methyl jasmonate induces synthesis of proteinase inhibitors in plant leaves. Proc. Natl. Acad. Sci. USA. 87:7713-7716.

Firn RD, Jones CG (1995) Plants may talk, but can they hear? Trends Ecol. Evol. 10:371.

Fowler SV, Lawton JH (1985) Rapidly induced defenses and talking trees: the devil's advocate position. Am. Nat.126:181-195.

Frost CJ, Mescher MC, Carlson JE, De Moraes C (2008) Plant defense priming against herbivores: getting ready for a different battle. Plant Physiol. 146:818-824.

Gershenzon J (2007) Plant volatiles carry both public and private messages. Proc. Natl. Acad. Sci. USA. 104:5257-5258.

Haukioja E, Suomela J, Neuvonen, S (1985) Long-term inducible resistance in a birch foliage: triggering cues and efficacy on a defoliator. Oecologia. 65:363-369.

Heil M, Bueno JCS (2007) Within-plant signaling by volatiles leads to induction and priming of an indirect plant defense in nature. Proc. Natl. Acad. Sci. USA. 104:5467-5472.

Herms DA, Mattson WJ (1992) The dilemma of plants: to grow or to defend. Q. Rev. Biol. 67:283-335.

Hildebrand DF, Brown GC, Jackson DM, Hamilton-Kemp TR (1993) Effects of some leaf-emitted volatile compounds on aphid population increase. J. Chem. Ecol. 19:1875-1887.

Karban R (2001) Communication between sagebrush and wild tobacco in the field. Biochem. Syst. Ecol. 29:995-1005.

Karban R. (2007) Experimental clipping of sagebrush inhibits seed germination of neighbours. Ecol. Lett. 10:791-797.

Karban R. (2008) Plant behaviour and communication. Ecol. Lett. 11:1-13.

Karban R, Agrawal AA, Thaler JS, Adler LS (1999) Induced plant responses and information content about risk of herbivory. Trends Ecol. Evol. 14:443-447.

Karban R, Baldwin IT (1997) Induced Responses to Herbivory. The University of Chicago Press, Chicago.

Karban R, Baldwin IT, Baxter KJ, Laue G, Felton GW (2000) Communication between plants: induced resistance in wild tobacco plant following clipping of neighboring sagebrush. Oecologia.125:66-71.

Karban R, Huntzinger M, Mccall AC (2004) The specificity of eavesdropping on sagebrush by other plants. Ecology 85:1846-1852.

Karban R, Maron J (2002) The fitness consequences of interspecifc eavesdropping between plants. Ecology 83:1209-1213.
Karban R, Maron J, Felton GW, Eichenseer H (2003) Herbivore damage to sagebrush induces resistance in wild tobacco: evidence for eavesdropping between plants. Oikos. 100:325-332.

Karban R, Shiojiri K, Huntzinger M, McCall AC (2006) Damage-induced resistance in sagebrush: volatiles are key to intra- and interplant communication. Ecology. 87:922-930.

Kessler A, Baldwin IT (2001) Defensive function of herbivore-induced plant volatile emissions in nature. Science. 291:2141-2144.

Kessler A, Halitsche R, Diezel C, Baldwin IT (2006) Priming of plant defense responses in nature by airborne signaling between Artemisia tridentata and Nicotiana attenuata. Oecologia.148:280-292.

Kost C, Heil M (2006) Herbivore-induced plant volatiles induce an indirect defence in nieghbouring plants. J. Ecol. 94:619-628.

Krebs JR, Davis NB (1997) Behavioural Ecology: an Evolutionary Approach. Blackwell, London.

Liechti R, FarmerEE (2002) The jasmonate pathway. Science. 296:1649-1650.

Lin H, Kogan M, Fisher D (1990) Induced resistance in soybean to the Mexican bean beetle (Coleoptera: Coccinellidae): comparison of inducing factors. Environ. Entomol. 19:1852-1857.

Mallik AU, Romeo JT, Pellissier F (eds) (2000) Special issue - allelopathy. J. Chem. Ecol. 26:2007-2241.

Mattson WJ (1980) Herbivory in relation to plant nitrogen content. Annu. Rev. Ecol. Syst. 11:119-161.

Mattson WJ, Haack RA (1987) The role of drought stress in provoking outbreaks of phytophagous insects. In: Barbosa P, Schultz JC (eds), Insect Outbreaks, pp.365-407. Academic Press, San Diego.

Paschold A, Halitschke R, Baldwin IT (2006) Using “mute" plants to translate volatile signals. Plant J. 45:275-291.

Pichersky E, Gershenzon J (2002) The formation and function of plant volatiles: perfumes for pollinator attraction and defense. Curr. Opin. Plant Biol. 5:237-243.

Preston CA, Laue G, Baldwin IT (2001) Methyl jasmonate is blowing in the wind, but can it act as a plant-plant airborne signal? Biochem. Syst. Ecol. 29:1007-1023.

Preston CA, Laue G, Baldwin IT (2004) Plant-plant signaling: application of trans- or cis- methyl jasmonate equivalent to sagebrush releases does not elicit direct defenses in native tobacco. J. Chem. Ecol. 30:2193-2214.

Preston CA, Lewandowski C, Enyedi AJ, Baldwin IT (1999) Tobacco mosaic virus inoculation inhibits wound-induced jasmonic acid-mediated responses within but not between plants. Planta. 209:87-95.

Rhoades DF (1983) Responses of alder and willow to attack by tent caterpillars and webworms: evidence for pheromonal sensitivity of willows. In: Hedin PA (ed), Plant Resistance to Insects, pp.55-68. American Chemical Society Symposium Series 208, Washington DC.

Rhoades DF, Cates RG (1976) Toward a general theory of plant anti-herbivore chemistry. In: Wallace JW, Mansell RL (eds), Biochemical interactions Between Plants and Insects, pp.168-213. Plenum Press, New York.

Roda AL, Baldwin IT (2003) Molecular technology reveals how the induced direct defenses of plants work. Basic Appl. Ecol. 4:15-26.

Sabelis MW, van Baalen M, Bakker FM, Bruin J, Drukker B, Eggas M, Janssen ARM, Lesna IK, Pels B, van Rijn P, Scutareanu P (1999) The evolution of direct and indirect plant defence against herbivorous arthropods. In: Brown $\mathrm{OH}$, Drent RH (eds), Herbivores: Between Plants and Predators, pp.109-166. Blackwell, Oxford.

Shonle I, Bergelson J (1995) Interplant communication revisited. Ecology. 76:2660-2663.

Sotka EE, Taylor RB, Hay ME (2002) Tissue-specific induction of resistance to herbivores in a brown seaweed: the importance of direct grazing versus waterborne signals from grazed neighbours. J. Exp. Mar. Biol. Ecol. 277:1-12. 
Stamp N (2003) Out of the quagmire of plant defense hypotheses. Q. Rev. Biol. 78:23-55.

Ton J, D'Alessandro M, Jourdie V, Jakab G, Karlen D, Held M, Mauch-Mani $B$, Turlings TCJ (2006) Priming by airborne signals boosts direct and indirect resistance in maize. Plant J. 49:16-26.

Tscharntke T, Thiessen S, Dolch R, Boland W (2001) Herbivory, induced resistance, and interplant signal transfer in Alnus glutinosa. Biochem. Syst. Ecol. 29:1025-1047.

Turlings TCJ, Tumlinson JH (1992) Systemic release of chemical signals by herbivore-injured corn. Proc. Natl. Acad. Sci. USA. 89:8399-8402.

Tuzun S, Bent E (2005) Multigenic and induced systemic resistance in plants. Springer, New York.
Loon JJAV, de Boer JG, Dicke M (2000) Parasitoid-plant mutualism: parasitoid attack of herbivore increases plant reproduction. Entomol. Exp. Appl. 97:219227.

Zangerl AR, Bazzaz FA (1992) Theory and pattern in plant defense allocation. In: Fritz RS, Simms EL (eds), Plant Resistance to Herbivores: Ecology, Evolution, and Genetics. pp.363-391. University Chicago Press, Chicago.

Zeringue HJ (1987) Changes in cotton leaf chemistry induced by volatile elicitors. Phytochemistry. 26:1357-1360.

Zeringue $\mathrm{HJ}$ (1992) Effects of $\mathrm{C}_{6}=\mathrm{C}_{10}$ alkenals and alkanals on eliciting a defence response in the developing cotton boll. Phytochemistry 31:23052308.

Zheng SJ, Dicke M (2008) Ecological genomics of plant-insect interactions: from gene to community. Plant Physiol. 146:812-817. 